\title{
Selfie and Self-Esteem
}

\author{
Jerald C. Moneva \\ Department of Education-Mandaue City Division \\ Mandaue City, Cebu, Philippines \\ Tel: +63908-927-3038Ｅ-mail: Freezingfire1979@gmail.com \\ Jhea A. Perolino \\ Jagobiao National High School \\ Jagobiao, Mandaue City, Cebu, Philippines \\ Tel: +63950-893-1438Ｅ-mail: perolinojhea@gmail.com \\ Sheila T. Ycong \\ Cebu City, Philippines \\ E-mail: sheilaycong@yahoo.com
}

Received: February 10, 2020

doi:10.5296/ijssr.v8i2.16792
Accepted: March 22, 2020 Published: April 2, 2020

URL: http://dx.doi.org/10.5296/ijssr.v8i2.16792

\begin{abstract}
Selfie is an image taken by them and later uploaded to social media such as Twitter, Instagram, Facebook and so on. Self-esteem is an important aspect of personality of the person. This study focused on why people are fond on taking selfie and posting selfie to the internet or social media networking is a factor leading to an increase individual's self-esteem. The study supported by the Looking Glass Self theory proposed by Charles Horton Cooley. The study was conducted to gather information from students towards on how their behavior on taking selfie in order for the researcher to asses if there is an association between the "selfie and students' self-esteem". This study has 145 respondents from the different strands in Senior High School. The tool used on this study is checklist rating scale questionnaire to collect data and information. All the data were analyzed using chi-square. The result revealed the p value is less than to the significant level. Therefore, the result of this study revealed that the selfie habits of the students can boost self-esteem.
\end{abstract}

Keywords: selfie, self-esteem, behavior, students 


\section{Introduction}

\subsection{Rationale}

Selfie is an image taken by them and later uploaded to social media such as Twitter, Instagram, Facebook and so on. Young people nowadays are addicted on taking selfie. They take selfie to boost their self-esteem. Selfie affects their self-esteem or their positive and negative results. Many students of the Senior High School were addicted on taking selfie. Student used their phone or Smartphone to take selfie or group selfie. Taking selfie has increased their admirers. They spend more time to take selfie than to study. When taking group selfie, the researcher observes that one of their friend say his/her friend to delete their photo where they are not looking good. Some of the student in the Senior High School, they take selfie during class hours and later uploaded in the social media.

The researcher observes that many people nowadays are very fond of selfie. There are people who consider selfie as a way to people become fond of them. Nowadays people take selfie if they are bored and make fun. Clicking selfie is just to make a better image of oneself in the social media. But in the real, they need to accept themselves the way they were. Young people nowadays prefer to take selfie compared to regular photography. Through Selfies will get deleted after a certain time. They take selfie because many people want to get attention from their friends and family. In addition, they take selfie because they feel alone, sad, broken hearted, and to express their feeling through taking selfies. Many people take selfies only when they look good and create occasions to take more selfies, to reduce their stress level by taking selfie. Especially posting selfie in social media that can result to increasing their admirers or can improve their confidence. The numbers of likes they have is a way for people to give their opinion.

According to Singh and Tripath (2016) many of today's generation Smartphone are equipped with high resolution camera, they call it the selfie camera. Though people were fond of taking photographs of their own and others since many decades, with selfie camera it has led to an extreme effect. Kwon (2011) said that young adults prefer selfie as compared to regular photography, because it shows the public how they see themselves instead of how they look. Lentanendi (2012) suggested that a psychological concept called the snow white "Looking Glass Self" causes one to develop his or her sense of self based on what how those closest to them perceive.

The researcher believes that "selfie" has a relation to individuals' self-esteem and would like to find out statistically.

\subsection{Theoretical Background}

This study is supported by Looking-Glass Self Theory, was created by American sociologist Charles Horton Cooley in 1902 and introduced into his own work "Human Nature and the Social Order. This theory described as what is our reflection of how we think we appear to others. The concept is not a person who is alone or it called solitary phenomenon. Cooley theorizes that human beings have the tendency to reach out, interact, or socialize with those people and objects that surround them. 
Charles Horton Cooley study the theory about self-image that you see your face, figure and also people use the self as a mirror. Looking-Glass Self theory relates directly to how people are practicing and using selfies nowadays. In addition, this theory stated that people who they are from others and from their imagination of how they appear to others.

Selfies are just like many other new media. The technology that made it possible for people to take selfies makes it possible for people to relate the picture as many times as they need to show the world the exact self-image and appearance they want others to see. People tend to use their imagination to see how they appear to others and what personality they reflect the self-image they have in their minds and want other people to see.

People nowadays prefer to use their cell phone than photograph. Selfie boost their self-esteem. Many people need a high self-esteem. They need more attention from other person. The self-esteem level depends on the person who react their photo/selfie. Young people nowadays, they take selfie just for fun and to increase their admirers.

In relation to the theory of Charles Horton Cooley talks about the self-image and our reflection of how we think we appear to others that has a correlation to the selfie and self-esteem.

\subsection{Statement of Purpose}

The study intends to determine the relationship between selfie and self-esteem, then the level of attitude of student toward making shoots and posting selfie, the level of self-esteem of student and to test the relationship between making shoots, posting selfie and self-esteem.

\subsection{Review of Related Literature}

In this study, selfie taking has become a major leisure activity and with the support of improved social media features. Selfie also considered a fad practice, but industry and a academics gave that dedication and significance to it (Balakrishnan \& Griffiths, 2018). Young women take selfie and later uploaded on social media are harmful in terms of their mood and self-image (Mills, Musto, Milliams, \& Tiggemam, 2018). For those who don't like to take selfie negatively associated with self-esteem and the self-esteem of individuals raises with selfie (Pandey \& Mishra, 2017). Selfie encourage people to take needles risks that are known to be fatal in some situations (Veena \& Krishnamurthy, 2015). Some people taking selfies because they kept it to be registered and remembered for several reasons (Shin, Kim, \& Chong, 2017).

Furthermore, some people shared a deep need for consideration of the negative consequences to be aware of the negative effects (Lobo \& Gowda, 2016). For those who are unable to profit from it and are passively exposed to it. Also having habits of sharing selfies can potentially have a negative result on self-esteem (Biolcati, 2019). Sport-self-presentation in social media is a special class. A woman has a lot of sharing selfies than men (Szabo \& Buta, 2019). Through a temperature posting of selfies can increase individuals self-esteem (Wang ${ }^{1}$, Wang ${ }^{2}$, Liu, Xic, \& Lei, 2018)- If-posting may represent low self-esteem or boost self-esteem; as such pictures usually emphasize the managed image of one's contract (Singh \& Tripathi, 2016). 


\section{MInstitute Macrothink $_{\text {Int }}$}

The self-esteem of every individual indirectly linked to adult depression through RS and weather the positive effect of this indirect relationship was moderated (Wang ${ }^{1}, \mathrm{Wang}^{2}$, Xic, $\mathrm{Wang}^{3}$, Wang ${ }^{4}$, Nic, \& Lei, 2018). Selfie practices aspect may be more closely related to the outcomes of well-being and body trust, including curating them. In addition finding and putting emphasis on peer input (Mclean, Jorman, \& Rodgers, 2019). Selfies are viewed more favorably than the selfies of others. Selfie had a strong preference of seeing more popular pictures in social media compared to selfies also showed more negative than positive effects. (Bruno, Sorokowska, Pinansik, \& Sorokowski, 2018). For student there are various disabilities of positive self-impacts and selfie raises one's perception or will improve their awareness and self-confidence (Sharma, 2016).

There are also female participants take selfies than males, female like to edit their selfies compared to males (Stefanone, Toh, \& Yue, 2018). It turns out that selfie creates individuals and users in different problematic ways because of the connection between digital technologies, growing visualization, and included the algorithmic culture (Cruz \& Thornham, 2015). Selfies have high socio-economic status as people become addicted with selfies are taken with advances in technology (Nagalingam, Arumugam, \& Preethy, 2019). Those who are addicted on taking selfie should aware the consequences, it's also need to worry about themselves (Charoensukmongkol, 2016). The students of college have become addicted on taking selfies and have become a common trend in their lives (Joy \& Venkatachalam, 2019). Some people who take selfies can felt good about their self by posting selfies on social networking platforms (Wickel, 2015).

Selfie also called selfitis that increase self-esteem and self-confidence (Mohan, Sund, \& Dubey, 2017). Selfies, mid-level detectors were then used to design user personality (Guntutu, Qiu, Roy, Lin, \& Jakhetiya, 2015). Selfie behavior or event causes narcissism among women or vice-versa is not mentioned (Amurao, 2016). Because of the use technology and be aware of self-protection measures, consumers can make informed choices (Pearson \& Hussain, 2016).Selfie/Groupie activities allow the attitude and social influence of students are almost comparable and significant (Limjuco \& Bautista, 2016).

In addition, in online self-presentation, individual differences seem to be of paramount importance (Harris \& Bardey, 2019). Snap chat account, is an app that we take selfie sometimes or can app that makes your picture look better, also increase individuals self-esteem (Miller \& Perkovic, 2018). Having Smart phones and shared your selfies on social network probably on WhatsApp had more narcissism symptoms after editing them (Kaur, Maheshwari, \& Sharma, 2018). And lastly, taking selfie or posting selfie doesn't matter the differences of age and gender (Boursier \& Manna, 2018).

\section{Research Method}

\subsection{Design}

This research study used descriptive correlation to the variables to determine the significant relation between selfie and self-esteem. 


\subsection{Environment}

This study was conducted in Senior High School which located to Mandaue City. It was conducted in the second floor and the new building of Senior High School.

\subsection{Respondents}

The respondents were all Senior High School students especially in Grade 11 and Grade 12 students. In Grade 11 STEM have 16 males and 19 females for a total with 35 respondents. There were 19 males and 24 females for a total with 43 respondents in Grade 11 HUMSS. There were 6 males and 24 females for a total with 30 respondents in Grade 11 ABM. There were 8 males in Grade 11 TVL. There were 14 males and 26 females for a total with 40 respondents in Grade 11 GAS. While in Grade 12, there were 8 males and 21 females for a total with 29 respondents in Grade 12 ABM. There were 8 males and 15 females for a total with 23 respondents in Grade 12 GAS. There were 14 males and 31 females for a total with 45 respondents in Grade 12 HUMSS. The total respondents are 250 students.

\subsection{Data Gathering Procedure}

The researcher needs to approach to the school head of the Jagobiao National High School Department and to every teacher or adviser of Grade 11 and Grade 12 to ask permission. When the permission was confirmed, the researcher was allowed to conduct study. The researcher would give checklist questionnaire to the students. After they answered, the researcher would collect the data. The data depends on the answer of the respondents. The gathered information will be used to evaluate and the process of the whole study.

\subsection{Instrument}

The researcher used questionnaire checklist as a tool and guide in gathering data. The researcher would conduct a question using the guide for the respondents and for the data and information to answer the problem. The first part of the checklist was adopted from the internet uploaded by Gill, T. and the second part of the checklist was adopted from the internet uploaded by Rose. A checklist is a list of term required, things to be done or points to be considered used as a reminder. For the purpose of gathering information for the respondents, the first part was indicating to the self-esteem of the person who addicted on selfie. The scoring 5-Strongly Agree, 4-Agree, 3-Uncertain, 2-Disagree, and 1-Strongly Disagree. 


\section{Macrothink

\section{Data Analysis and Discussion}

Table 1. Level of attitude towards selfie

\begin{tabular}{lll}
\hline Indicators & WM & Interpretation \\
\hline 1. Selfies empower me & 2.85 & Uncertain \\
2. I create occasions to take more selfies & 2.58 & Disagree \\
3. I usually spend more time taking selfies than I intend to & 2.39 & Disagree \\
4. Everything I do I imagine it as a selfie & 2.26 & Disagree \\
5. Initially I thought I would be judged for taking selfies but now it is an & 2.95 & Uncertain \\
accepted normal behavior & & \\
6. I pester my friends to delete a group selfie where I am not looking good & 3.17 & Uncertain \\
7. I read online about how to take the perfect selfies & 2.17 & Disagree \\
8. I take selfies only when I look good & 3.15 & Uncertain \\
9. Selfies help me control the way others think of me & 2.60 & Disagree \\
10. Selfies have helped me create a narrative through images & 2.86 & Uncertain \\
11. Selfies mold the way I perceive things & 2.72 & Uncertain \\
12. I spend some time before a mirror before I click a selfie & 2.71 & Uncertain \\
13. Clicking selfies has increased my admirers & 2.38 & Disagree \\
14. It is a ritual for me to click a selfie every time I go out somewhere & 2.50 & Disagree \\
Overall Weighted Mean & 2.66 & Uncertain \\
\hline Scale 1.00-1.80(Strongly Disagree), 1.81-2.60(Disagree), 2.61-3.40(Uncertain), 3.41-4.20(Agree), 4.21 \\
5.00(Strongly Agree)
\end{tabular}

The table indicates the indicators of people who used to take selfie. The overall weighted mean was 2.66 interpreted as uncertain. The three highest weighted mean are "I pester my friends to delete a group selfie where I am not looking good", “I take selfies only when I look good" and "Initially I thought I would be judged for taking selfies but now it is an accepted normal behavior" which are interpreted as Uncertain. The three lowest weighed mean are "I read online on how to take the perfect selfies", "Everything I do I imagined it as a selfie" and "Clicking selfies has increased my admirers" interpreted as Disagree. Female has a lot of sharing and posting selfies than males (Stefanone, Toh, \& Yue, 2018). For those who are addicted on taking selfie need to worry themselves and be aware the consequence (Charoensukmongkol, 2016). People didn't care about their selfies on posting or sharing their body size can affects them negatively (Mills, Musto, Milliams, \& Tiggemam, 2018). 
Table 2. Frequency of level of attitude towards selfie

\begin{tabular}{lllll}
\hline & Frequency & Percent & Valid Percent & Cumulative Percent \\
\hline Not fond of selfie & 3 & 2.1 & 2.1 & 2.1 \\
Slightly fond of selfie & 26 & 17.9 & 17.9 & 20.0 \\
Fairly fond of selfie & 68 & 46.9 & 46.9 & 66.9 \\
Moderately fond of selfie & 42 & 29.0 & 29.0 & 95.9 \\
Fond of selfie & 6 & 4.1 & 4.1 & 100.0 \\
Total & 145 & 100.0 & 100.0 & \\
\hline
\end{tabular}

Out of having 145 respondents, there were a highest frequency of 68 respondents who were "Fairly fond of selfie," there were 42 respondents who were "Moderately fond of selfie" and there were also respondents who were also "Slightly fond with selfie" with a frequency of 26. However, selfie doesn't matter the differences of age and gender (Boursier \& Manna, 2018). Selfie can increase people self-esteem and confidence (Mohan, Sund, \& Dubey, 2017).

Table 3. Level of self-esteem

\begin{tabular}{lll}
\hline Indicators & WM & Interpretation \\
\hline 1. I feel that I'm a person of worth, at least on an equal plane with others & 2.66 & Uncertain \\
2. I feel that I have a number of good qualities & 2.70 & Uncertain \\
3. I am inclined to feel that I am failure & 2.66 & Uncertain \\
4. On the whole, I am satisfied with myself & 2.72 & Uncertain \\
5. I certainly feel useless at times & 2.74 & Uncertain \\
6. I had more respect for myself & 2.83 & Uncertain \\
7. I am able to do things as well as most other people & 2.79 & Uncertain \\
8. I take positive attitude toward myself & 2.77 & Uncertain \\
9. I think I am no good at all & 2.88 & Uncertain \\
10. I do not have much to be proud of & 2.71 & Uncertain \\
Overall Weighted Mean & 2.75 & Uncertain \\
\hline
\end{tabular}

Legend: 1.00-1.80(Strongly Disagree), 1.81-2.60(Disagree), 2.61-3.40(Uncertain), 3.41-4.20(Agree), 4.21 5.00(Strongly Agree)

The table indicates the weighted mean of the indicators of self-esteem. The overall weighted mean is 2.75 interpreted as Uncertain. The three highest weighted mean are "I think I am no good at all", "I had more respect for myself" and ". I am able to do things as well as most other people" which are interpreted as Uncertain. The three lowest weighted mean are ". I feel that I'm a person of worth, at least on an equal plane with others", "I am inclined to feel that I am failure" and "I feel that I have a number of good qualities" which are interpreted as Uncertain. Having a "Snap chat" account makes your picture look better, also can increase your 
self-esteem (Miller \& Perkovic, 2018). Selfies are viewed more favorably than the selfies of others. Selfie had a strong preference of seeing more popular pictures in social media compared to selfies also showed more negative than positive effects. (Bruno, Sorokowska, Pinansik \& Sorokowski, 2018).

Table 4. Frequency of level of self-esteem

\begin{tabular}{lllll}
\hline & Frequency & Percent & Valid Percent & Cumulative Percent \\
\hline Low Self Esteem & 8 & 5.5 & 5.5 & 5.5 \\
Fair Self-Esteem & 22 & 15.2 & 15.2 & 20.7 \\
Average Self Esteem & 61 & 42.1 & 42.1 & 62.8 \\
High Self-Esteem & 43 & 29.7 & 29.7 & 92.4 \\
Very High Self Esteem & 11 & 7.6 & 7.6 & 100.0 \\
Total & 145 & 100.0 & 100.0 & \\
\hline
\end{tabular}

Out of 145 respondents, 61 have an average self-esteem, 43 of the respondents have a high self-esteem and 22 of them have fair self-esteem. Thus, other respondents have low and very high self-esteem. In addition, the self-esteem of every individuals indirectly linked to adult depression through response shift (RS) and weather the positive effect of this indirect relationship was moderated (Wang ${ }^{1}$, Wang ${ }^{2}$ Xic, Wang ${ }^{3}$, Wang ${ }^{4}$, Nic \& Lei, 2018). Self-esteem involves emotions and feelings that can affect the perspective of individuals towards their selves (Schwalbe \& Staples, 1991). Moreover, to have a high self-esteem, self-concept should be considered (Trautwein, Ludtke, Koller \& Baumert, 2006).

Table 5. Relationship between selfie and students' self-esteem

\begin{tabular}{llll}
\hline & Value & df & Asymp. Sig. (2-sided) \\
\hline Pearson Chi-Square & $1.4512^{\mathrm{a}}$ & 16 & .000 \\
$\mathrm{~N}$ of Valid Cases & 145 & & \\
\hline
\end{tabular}

a. 16 cells (64.0\%) have expected count less than 5. The minimum expected count is 17.

In these result, the null hypothesis is reject. Because the p-value is (.004), is lesser than the significance level (0.05). Selfie and self-esteem of the students are associated of each other. The selfie habit of the students can boost their self-esteem. Some reasons why people take selfie it's because they keep it as a memory (Shun, Kim, \& Chong, 2017). On the contrary, some people took selfie and posting their selfie can felt good about their self (Wickel, 2015). Selfie represent low self-esteem or boost self-esteem (Singh \& Tripathi, 2016). 


\section{Macrothink}

\section{Findings}

The data presented that the students is not certainly taking selfie it's just having fond taking it. Base on the interpreted data the overall weighted mean of the selfie students are doubtful. The level of students' self-esteem is moderate but they are tending to be more confident than to have a low self-esteem. On the interpreted data students have doubtful self-esteem and it is interpreted as Uncertain. Selfie and students' self-esteem are correlated to each other.

\section{Conclusion}

People who are fond on taking selfie are expected that their self-esteem will increase or boost individual's confidence and lighten up their mood, makes the students happy, and reduce students stress and increase students' self-esteem. Students who took selfie improve their self-esteem or they felt good on taking selfie. The self-esteem of the students is based on their attitude or behavior towards on taking selfie.

\section{Recommendation}

Based on the finding of the study, students can identify that taking selfie have an impact towards their self-esteem.

\section{References}

Amurao, R. M., \& Mastronuevo, (2016). Selfie Behavior and Narcissism among selected Females. The Bedan Journal of Psychology, 1. Retrieved from https://www.semanticscholar.org/paper/Selfie-Behavior-and-Narcissism-among-selected-\%2 C-Castronuevo/c66b81798765e60b7396119fb73bb8f6e1ad9eb8

Balakrishnan, J., \& Griffiths, M. (2018). An Exploratory study of "Selfitis" and the Development of the Selfities Behavior Scale. Int J Ment Addition.

Bioleati, R. (2019) Low self-esteem and selfie posting among young women. The Open Psychology Journal, 12, 155-160. https://doi.org/10.2174/1874350101912010155

Boursier, V., \& Monna, V. (2018). Selfie expectancies among adolescents: construction and validation of an instrument to assess expectancies toward selfies among boys and girls. Frontiers in Psychology, 9(839). https://doi.org/10.3389/fpsyg

Bruno, N., Sorokowska, A., Pisanski, \& Sorokowski, P. (2018) Editorial: understanding selfies. Frontiers in Psychology. https://doi.org/10.3389/978-2-88945-465-5

Charoensukmongkol, P. (2016). Exploring personal characteristics associated with selfie-liking. Cyberpsychology: Journal of Psychosocial Research on Cyberspace, 10(2). https://doi.org/10.5817/CP2016-2-7

Dom, J., \& Venkatachalan, J. (2019). Personality and selfie-liking behavior among student's college students. Retrieved from https://www.researchgate.net/publication/333802385_Personality_and_Selfie-Liking_Behavi our_among_College_Students 
Gomez Cruz, E., \& Thornham, H. (2015). Selfies beyond self-representation: the (theoritical) $\mathrm{f}(\mathrm{r})$ iction of a practice. Journal of Aesthetic \& Culture, 7. https://doi.org/10.3402/jac.v7.28073

Guntuku, S. C., Qiu, L., Roy, S., Lin, W., \& Jakhetiya, V. (2015) Do others perceive you as you want them to? Modeling Personality based on Selfie.

Limjuco, R., \& Bautista, V. (2016). Students' behavioral intentions to intentions to indulge in selfie and groufie activities: A path analysis. IJABER, 14(2), 1219-1235. Retrieved from https://www.researchgate.net/publication/304887891_Students'_behavioral_intentions_to_ind ulge_in_selfie_and_groufie_activities_A_path_analysis

Mclean, J. H., \& Rodgers, R. (2019). how do "selfie" impact adolescents' well-being and body confidence? A narrative review. Psychology Research and Behavior Management. Retrieved

from https://www.researchgate.net/publication/334326418_How_do_selfies_impact_adolescents'_ well-being_and_body_confidence_A_narrative_review

Mohan, P., Sunda, S., \& Dubey, P. (2017) Selfitis: selfie craze and addiction. Research Journal of Management Science, $\quad 6, \quad 12-21$. http://www.isca.in/IJMS/Archive/v6/i6/3.ISCA-RJMS-2017-061.php

Nagalingan, S., Arumunngam, B., \& Preethy, T. (2019). Selfie addiction: the prodigious self-portrait. International Journal of Research in Media Science, 694-698. https://doi.org/10.18203/2320-6012.ijrms20190919

Pandey, V., \& Mishra, B. P (2017). Assess the relationship between selfies and self-esteem among university students. Journal of Humanities and Social Science, 22(12), 24-30.

Sharma, A. (2016). A study of impact of self-portraits (selfie) on self-image of disable students studying in higher education. International Journal of Education and Applied Sciences Research, 3(6), 12-21. Retrieved from https://arseam.com/sites/default/files/published-papers/abstracts/Paper-2\%20\%20Issue-6\%20 \%20Abstract $\% 20 \% 2012-21 \% 20 \% 20$ Dr.\%20Arvind\%20Sharma\%20\%20Aug-Oct-2016.pdf

Shin, Y., Kim, M., Im, C., \& Chong, C. (2017). Selfie and self: the effect of selfies on self-esteem and social sensitivity. Journal of Personality and Individual Differences. https://doi.org/10.1016/j.paid.2017.02.004

Singh, S., \& Tripathi, K. M. (2016). Selfie: A new obsession. SSRN Electronic Journal. https://doi.org/10.2139/ssrn.2920945

Srivastava, S., Upadhaya, P., Sharma, S., \& Gupta, K. (2018). Exploring factors behind offline and online selfie popularity among youth in India. Frontiers in Psychology. https://doi.org/10.3389/fpsyg.2018.01403

Stefanone, M., Toh, Z., \& Yue, Z. (2018). A social cognitive approach to traditional media content and social media use: selfie-related behavior as competitive strategy. New Media and Society, 1-19. https://doi.org/10.1177/1461444818795488 


\section{Macrothink}

International Journal of Social Science Research

ISSN 2327-5510

2020, Vol. 8, No. 2

Szabo, A., \& Buta, L. (2019). Sport-selfies: characteristics and differences in gender, ethnic and national origin, type, form, and milieu of sports. Society and Leisure. https://doi.org/10.1080/07053436.2019.1625643

Veena, G., \& Krishnamurthy, M. (2015). Perception towards capturing selfies and its impact among students of Mangalore University: A study. International Journal of Digital Library Services, 5(4). http://www.ijodls.in/uploads/3/6/0/3/3603729/2545.pdf

Wang, Y., Wang, X., Liu, H., Xie, X., Wang, P., \& Lei, L. (2018). Selfie posting and self-esteem among young adult women: A mediation model of positive feedback and body satisfaction. Journal of Health Psychology, 1-12, https://doi.org/10.1177/1359105318787624

Wickel, T. (2015). Narcissism and social networking sites: the act of taking selfies. The Elon Journal of Undergraduate Research in Communications, 6(1). Retrieved from http://www.ijodls.in/uploads/3/6/0/3/3603729/2545.pdf

Zhao, S., \& Zappavigna, M. (2018). The interplay of (semiotic) technologies and genre: The case of the selfie. Social Semantics. https://doi.org/10.1080/10350330.2018.1504724

\section{Glossary}

For the better understanding of the study, the following term are operationally defined:

Selfie - Is an image taken by student or a photograph that one has taken of oneself, typically one taken with a smartphone or webcam and shared via social media.

Self-esteem - Is a level of a student's behavior toward her or himself and it is an individual's subjective evaluation of their own worth.

\section{Appendix}

Survey Questionnaire for selfie and students' self-esteem

\section{TOOL: CHECKLIST}

Name:

Gender:

Grade \& Section:

Age:

Directions: Please put check and rate yourself honesty based on what you actually do in the given statements using the following scales.

5-Strongly Agree 4-Agree 3-Uncertain 2-Disagree 1-Strongly Disagre 
Selfies empower me

I create occasions to take more selfies

I usually spend more time taking selfies than I intend to

Everything I do I imagine it as a selfie

Initially I thought I would be judged for taking selfies but now it is an accepted normal

behavior

I pester my friends to delete a group selfie where I am not looking good

I read online about how to take the perfect selfies

I take selfies only when I look good

Selfies help me control the way others think of me

Selfies have helped me create a narrative through images

Selfies mold the way I perceive things

I spend some time before a mirror before I click a selfie

Clicking selfies has increased my admirers

It is a ritual for me to click a selfie every time I go out somewhere

Source: https://www.slideshare.net/mobile/TanyaGill/selfie-the-new-age-media-trend

\section{Il. Self-esteem}

I feel that I'm a person of worth, at least on an equal plane with others.

I feel that I have a number of good qualities

I am inclined to feel that I am fail

On the whole, I am satisfied with myself

I certainly feel useless at times

I had more respect for myself

I am able to do things as well as most other people

I take positive attitude toward myself

I think I am no good at all

I do not have much to be proud of

Source: https://www.researchgate.net/figure/ROSENBERG-SELF-ESTEEM-SCALE_tbl1_267399760

\section{Copyrights}

Copyright for this article is retained by the author(s), with first publication rights granted to the journal.

This is an open-access article distributed under the terms and conditions of the Creative Commons Attribution license (http://creativecommons.org/licenses/by/4.0/). 